Volume 2 No. 1, Februari 2019

\title{
SOCIAL VARIATIONS OF LANGUAGE USER (EDUCATION, JOB, AND SOCIAL PRANATA)
}

\author{
Fadilla Oktaviana $^{1}$, Ina Rohiyatusakinah ${ }^{2}$ \\ Banten Jaya University \\ Serang Indonesia \\ fadillaoktaviana@unbaja.ac.id ${ }^{1}$, inarohiyatusakinah@unbaja.ac.id ${ }^{2}$
}

\begin{abstract}
This study aims to describe the social variation of language based on education level, type of work, and social institutions on Facebook users with an age range of 24-50 years. The source of data in this study is the status written on social media in this case facebook. The data collection technique is done by referring to the note taking technique. The data analysis technique used is content analysis. The results of the analysis show that the educational background, the type of work that is owned and the social institutions possessed by the users of the language are very influential in the content of writing, choice of words and writing when communicating. Although not a single factor because there are still many other factors that affect such as psychology, writing style, and others.
\end{abstract}

Keywords: Social variation, language users, education, work, social institutions.

\section{A. Introduction}

In a complex social life, it is natural if later there are various variations in a language. Even more so when viewed from a variety of different points of view. Paying attention to the way people use language in different social contexts provides a wealth of information about how the language works, how the social relationships of these people in a community, and how they signal each other aspects of their social identity through the language used.

$$
\text { Various language variations in }
$$
social life are a treasure of human culture. In this case the language variations that occur in society are not only influenced by linguistic factors but also non-linguistic factors. namely: (a) social factors, for example: social status, education level, age, economic level, gender, etc. and (b) situational factors, for example: who speaks in what language, to whom, when, where and about what problem. The existence of social factors and situational factors that influence language use, there arises language variations. Language variations are part forms or variants in languages that each have patterns that resemble the general pattern of the parent language. The form of language variation can be viewed from a variety of aspects, including: aspects of speakers, aspects of 
use, aspects of formality, and facets of facilities.

Language variations based on the speakers or users of the language as explained above are influenced by social factors. In this paper the social factors that influence language variations that will be discussed are in terms of education, employment, and social institutions. This is to provide an in-depth understanding of language variations in terms of speakers.

\section{B. Theoretical Framework}

\section{Social Variation of Language Users}

Language variations occur because of the very wide area of use and various speakers. Interactions between one with other people who are different, historical factors, and the development of society also influence the language so that it changes into a variety of languages. So diversity in language is a necessity and consequence of the extent of the area of use.

There are two views in terms of language variations. First, variation is seen as a result of the social diversity of the speakers of the language and the diversity of language functions. second, the variety of languages already exists to fulfill its function as a means of interaction in diverse community activities. These two views can be accepted or rejected. But what is certain is that language variations can be classified based on the existence of social diversity and the function of activities in social societies. This is different from Halliday's view, which distinguishes variations in language based on user (dialect) and usage (register).

In various sources divide the variety of languages into several aspects, namely (1) Based on the area of use, (2) Based on the level of education of speakers, (3) Based on the attitude of speakers, (4) Based on the field or subject matter surrounding speakers, (5) Based on means, variety of oral and various writing Social life in society greatly influences language behavior. Social position or social class refers to groups of people who have certain similarities in the social field such as economy, employment, caste, and so on.

\section{Language and Education}

Social variations of language users can be viewed from social status and education is one form of social status whose existence is clearly visible in society. Chaer and Agustina (2010: 65) reveal that differences in language variations based on education can not only be seen in the content of the conversation 
but also vocabulary, pronunciation, morphology, and syntax. This opinion is also in line with Bernstein's theory (in Sumarsono, 2011: 53) which states that there are two kinds of speaker languages, namely detailed code and limited code. Detailed codes are commonly used in formal situations or in academic situations. Its characteristics refer to a variety of high and quality languages, such as using a lot of the words "I" in language, using foreign languages well, or using grammatically arranged languages. Limited codes are more likely to be nonformal situations. This code is generally bound by context.

\section{Language and Work}

Language variations bkkased on profession are variations of language related to the type of profession, work and duties of the users of the language. Each job has its own register. Wardhaugh (2006) describes registers as a set of 'language items' that relate specifically to certain social groups or occupational groups. Doctors, pilots, bank managers, traders, public transportation drivers, musicians, or even those who work in the world of prostitution have their own registers. As revealed by Ferguson (1994 in Wardhaugh, 2006) 'People who dwell in recurring communication situations tend to develop similar vocabulary, intonation and syntactic and phonological characteristics that they use in these situations. ' This type of variation is called a register. Ferguson added that khusus specific terms for certain repetitive objects or events seem to help communication to be 'fast'. Below is an example of variations in language relating to work.

Examples of language variations used in the medical field for example: "Encephalitis can be caused by bacterial infections, such as meningitis, or complications from other diseases such as rabies (caused by a virus) or syphilis (caused by bacteria). Parasitic and protozoan diseases such as toxoplasmosis, malairia or primary amoebic meningoencephalitis, can also cause encephalitis in people whose immune systems are lacking. "

Examples of language variations in the field of law for example: "Arraignment is a common law term for official criminal complaint readings before defendants to notify the accused of him. In response, he is expected to express recognition, for example "guilty", "innocent", peremptory plea, nolo contendere, or Alford plea. In England, arraignment is the first 11 stages 
in the court, and involves a clerk of the court reading allegations. "

Registers that are used by someone can reflect the person's background. Of course, one can control the variety of registers that he uses; someone might have more than one profession. Each register will help reveal who someone is at a particular time and place. This register can also be used to measure whether someone is 'better' or 'worse' than someone else who is with him.

\section{Language and Social Institution}

Furthermore, the social variation of language users on speakers can be seen based on social institutions. Social institutions are an official system of norms in society to regulate behavior in order to make ends meet. The views related to language variations in social institutions are the Sapir-Whorf Hypothesis.

The hypothesis proposed by Edward Sapir and Benjamin Lee Whorf is closely related to culture. This hypothesis (through Cahyono, 1995: 417) states that speakers of languages classify the world according to the boundaries outlined by their native language. However, the SapirWhorf hypothesis cannot be fully accepted because there are many factors that must be seen in language users. These factors are:
1) Physical environment. The environment can affect the language of the community which is usually in the vocabulary of words. For example non Eskimos in terms of speakers of English have an understanding of snow is snow with various types of snow such as wet snow, soft snow, liquid snow, snow on the ground, chunks of snow, and so on while in Eskimo people have names different with different circumstances and forms.

2) Social environment. The social environment can reflect and influence the structure of vocabulary in language for example: (1) The word family, in the American family includes a family that consists of husband, wife, and children while in Indonesian the family can include people outside of husband, wife, and their children, (2) The English call all the brothers and sisters of the father and mother in one term, uncle (uncle), while the Batak have a different calling for the younger brother of the father and mother called Uda/Amanguda, the father and mother's older brother was called Tulang. (3) The Englishman calls his child by the nickname of the child 
only. The Javanese call to call their child by name or le, nang (for men) and wuk, nduk (for women). Batak people who call their children by name or mang (for men) and nang, boru (for women) then Balinese call de (from gede), deck (from kadek), man (from nyoman), and tut (from ketut) ) according to the order of birth.

3) Layers of society and castes. Layers and castes in society give rise to levels in the language of communication. This can be seen clearly in several tribes in Indonesia which have caste systems such as Bali and Java. The use of language looks different when used by certain people in their respective castles. In Balinese society there are four castes namely Brahmana, Knight, Vaishya, and Sudra. Brahmins are a group of priests and clergy in a society and are the most respected group. Knights are a group of nobles who pursue government or state administration and are experts in the military field and are adept at using weapons. Wesia is a group of traders, farmers, fishermen, and other professions including the field of commerce or work that handles everything that is material, such as food, clothing, property, and so on. Shudras are a group of servants who help the Brahmana, Knight and Wesia groups so that their work can be fulfilled. Here are some examples of differences in language use in Balinese society.

Example:

The difference used to call parents, such as:

Brahmana: Aji for father and $I b u$ for mother

Kstaria: Aji for father and biang for mother

Sudra: bapak/guru for father and Meme for mother

\section{Research Methods}

In accordance with the problem and the purpose of the study, this study uses a descriptive qualitative method approach, because what is examined is verbal language in the form of writings that are in social media status in this case facebook. In this study, the status of research objects in social media was explained based on different levels of education, employment and social institutions in the age range of 24-50 years. Then an analysis of the variety of languages used is then carried out. 


\section{Data and Data Sources}

The data in this study are text or status in social media in this case Facebook is generated by respondents with different levels of education, types of work, and social institutions. Text or status on social media analyzes 3 texts from each respondent. The data of this study were taken from respondents in the adult age range of 24-50 years who are active in social media Facebook

\section{E. Data Analysis}

The data in this study were analyzed by carrying out the following steps:

1. The researcher collects all the statuses of the respondents who match the criteria.

2. Language and education variations are analyzed using Chaer and Agustina's theory (2010: 65) which reveals that differences in language variations based on education can not only be seen in the content of the conversation but also vocabulary, pronunciation, morphology, and syntax.

3. Variations in language and type of work are analyzed using the Wardhaugh (2006) theory which describes registers as a set of 'language items' that relate specifically to certain social groups or occupational groups
4. Language variations and social institutions analyzed using Edward Sapir and Benjamin Lee Whorf are closely related to culture. This hypothesis (through Cahyono, 1995: 417) states that speakers of languages classify the world according to the boundaries outlined by the original language they have

5. The researcher makes conclusions about the use based on the level of education, different types of work and social institutions.

\section{F. Research Findings}

1. Analysis of Social Variations in Language Users based on Education, Employment, and Social Institutions

a) Analysis of Social Variation of Language Users based on Education

As an example of the social variation of language based on education, the following is attached to the status on some Facebook social media accounts that have been categorized based on the age range of 24-30 years with junior high, high school, S1 and S2 education.

Name of Education Status on Facebook 


\begin{tabular}{|c|c|c|}
\hline Name & Education & $\begin{array}{c}\text { Statement in } \\
\text { facebook }\end{array}$ \\
\hline \multirow[t]{2}{*}{$\begin{array}{l}\text { Meyy } \\
\text { Claluu } \\
\text { Cndily }\end{array}$} & SMP & $\begin{array}{lr} & \text { "Tuhan } \\
\text { percaya engkau } \\
\text { pasti } \\
\text { merencanakn yg } \\
\text { trbaik untk driku }\end{array}$ \\
\hline & & 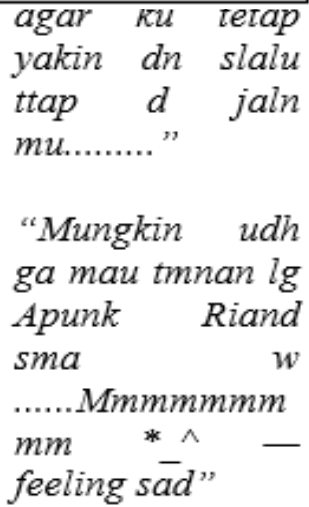 \\
\hline $\begin{array}{l}\text { Selvie } \\
\text { zee }\end{array}$ & SMA & 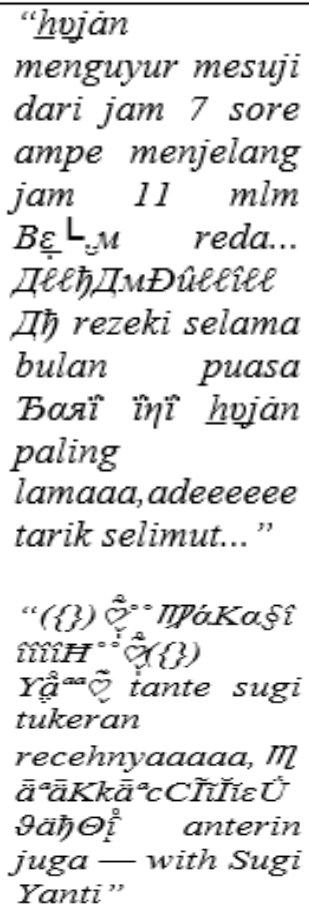 \\
\hline $\begin{array}{l}\text { Taufiq } \\
\text { Hidayat }\end{array}$ & S1 & 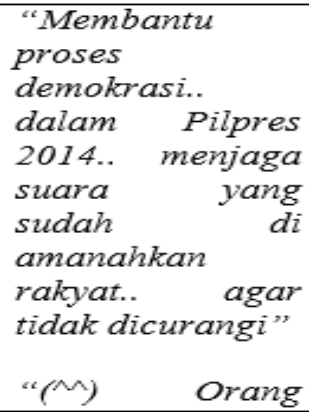 \\
\hline
\end{tabular}

\begin{tabular}{|c|c|c|}
\hline & & $\begin{array}{l}\text { yang tidak mau } \\
\text { mencoba untuk } \\
\text { bergerak } \\
\text { mengerjakan } \\
\text { keinginanya, } \\
\text { maka ia akan } \\
\text { berusaha } \\
\text { mengemukakan } \\
\text { berbagai alasan } \\
\text { dan kendalanya } \\
\text { sebelum } \\
\text { mencoba... "S } \\
\text { \# "Selamat } \\
\text { Mencoba" }\end{array}$ \\
\hline $\begin{array}{l}\text { Yani } \\
\text { supriani }\end{array}$ & $\mathrm{S} 2$ & 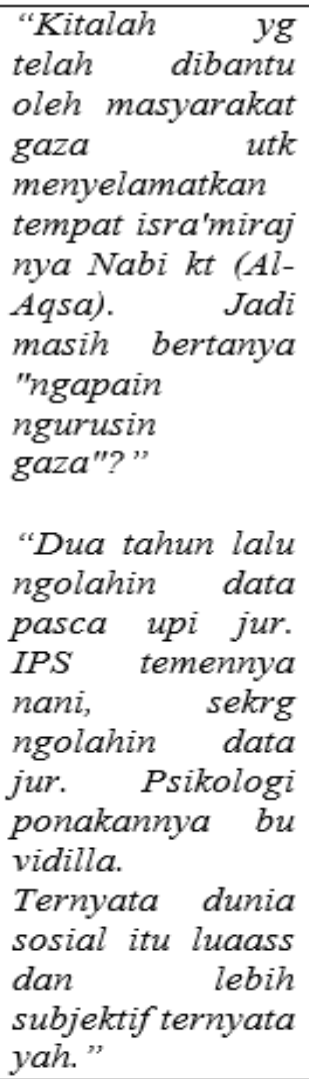 \\
\hline
\end{tabular}

Based on the Facebook status above taken randomly with different levels of education can be analyzed as follows: Meyy Claluu Cndily is an object with a junior high education level there are still some mistakes in writing Indonesian, writing word $a k u$, this error is also seen that I am not can stand alone 
because it is a possessive pronoun which must be accompanied by the previous noun, you who refer to the word God are not written in capital letters at the beginning, engkau which refers to the Tuhan did not write in capital letter, tlah(telah), trbaik (terbaik), untk(untuk), driku(diriku), $d n$ (dan), slalu (selalu), ttap (tetap),d jaln (dijalan) and mu which refers to God or ALLOH SWT must be written in capital letter $M u$. In the second statement, udh(udah), tmnan (temenan), lg (lagi),sma (sama), w (gue),Mmmmmmmmm linguistically there is no meaning inside, dan $*_{-} \wedge$ - feeling sad is an aplication provided by facebook.

The second object is selvie zee with a high school education level that already has better writing skills than the first grade. Although there are still a number of mistakes such as how to replace the words until, mlm (malam), lamaaa (lama) and writing

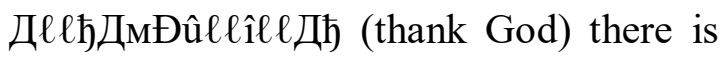
by using the application on BBM. On the second status, again he uses the BBM application to write (\{\})

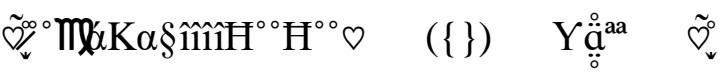

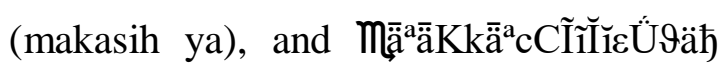
(makasih sudah), and $\Theta \stackrel{i}{1}$ anterin (dianterin).
The third object of research, Taufiq Hidayat with a Bachelor level of education, has a writing ability that is more neatly arranged, clear and easily understood. Fill in the status is no longer just writing personal activities but related to the issue that is developing. In writing it also no longer uses abbreviations, there is only one mistake in writing $d i$ on the word di amanahkan that is written that should be written not separately diamanahkan.

The fourth object, Yani Supriani, with a master's / master's level of education is not much different from the one with a bachelor degree, it's just that there are still a few mistakes like us kita lah should be written not apart kitalah, yg (yang), utk (untuk), dan kt (kita). In the second status, the word ngolahin is a nonstandard word to become (mengolahkan), jur (jurusan), sekrg (sekarang), ngolahin (mengolahkan),

ponakannya (keponakannya), and luaass (luas).

Based on the analysis of the status of social media accounts, it can be concluded that the educational background is quite influential in the content of the talk / status in the vocabulary social media used, pronunciation, morphology, and syntax. As stated by Chaer and Agustina (2010: 
Volume 2 No. 1, Februari 2019

Universitas Banten Jaya

65) reveals that differences in language variations based on education can not only be seen in the content of the conversation but also vocabulary, pronunciation, morphology, and syntax.

\section{b) Analysis of Social Variation of}

\section{Language Users by Work}

As an example of the social variation of language based on work, the following is attached to the status of several social media accounts of Facebook national figures who have been categorize based on the age range of 2430 years with the work of lecturers, teachers, writers, and researchers.

\begin{tabular}{|c|c|c|}
\hline Name & $\begin{array}{c}\text { Occupati } \\
\text { on }\end{array}$ & $\begin{array}{l}\text { Statement in } \\
\text { facebook }\end{array}$ \\
\hline $\begin{array}{l}\text { Yudi } \\
\text { Juniardi }\end{array}$ & Dosen & $\begin{array}{l}\text { "do something. } \\
\text { dengan dalih } \\
\text { apapun tidak } \\
\text { dibenarkan } \\
\text { suatu negara } \\
\text { menyerang } \\
\text { secara militer } \\
\text { kedaulatan } \\
\text { negara lain. } \\
\text { jika ia anggota } \\
\text { pbb, maka ia } \\
\text { akan } \\
\text { dikeluarkan } \\
\text { keanggotaanny } \\
\text { a, seperti yg } \\
\text { pernah dialami } \\
\text { Indonesia. tapi } \\
\text { mengapa } \\
\text { negara } \\
\text { adidava, dewan }\end{array}$ \\
\hline
\end{tabular}

P-ISSN 2623-0062

E-ISSN 2622-9056

\begin{tabular}{|c|c|c|}
\hline & & 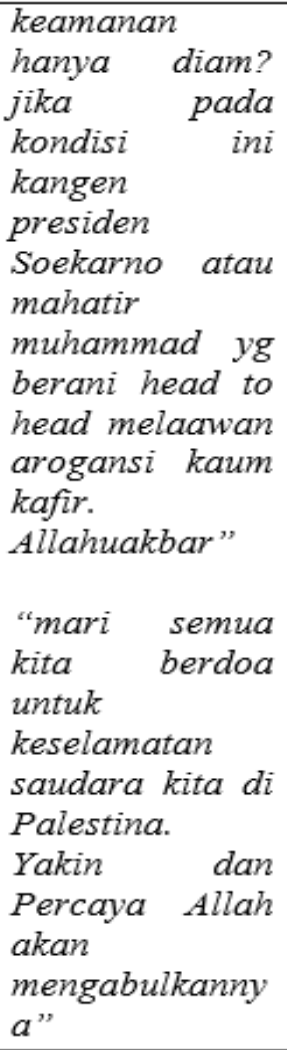 \\
\hline $\begin{array}{l}\text { Hulman } \\
\text { Fajri }\end{array}$ & Guru & $\begin{array}{l}\text { "ketika } \\
\text { manusia sudah } \\
\text { dapat } \\
\text { menempatkan } \\
\text { dirinya sesuai } \\
\text { dengan } \\
\text { tugasnya, maka } \\
\text { kebaikan yang } \\
\text { akan tercapai... } \\
\text { semoga..." } \\
\text { \#perjalananrah } \\
\text { asia } \\
\text { "peer teaching, } \\
\text { siapa takut...!!! } \\
\text { Lagi browsing } \\
\text { nih } \\
\text { hahahahaha... } \\
\text { Nyari bahan } \\
\text { besok peer } \\
\text { teaching }\end{array}$ \\
\hline
\end{tabular}


Volume 2 No. 1, Februari 2019

Universitas Banten Jaya

\begin{tabular}{|c|c|c|}
\hline & & kur 13" \\
\hline $\begin{array}{l}\text { Nassirun } \\
\text { Purwokart } \\
\text { un }\end{array}$ & Penulis & 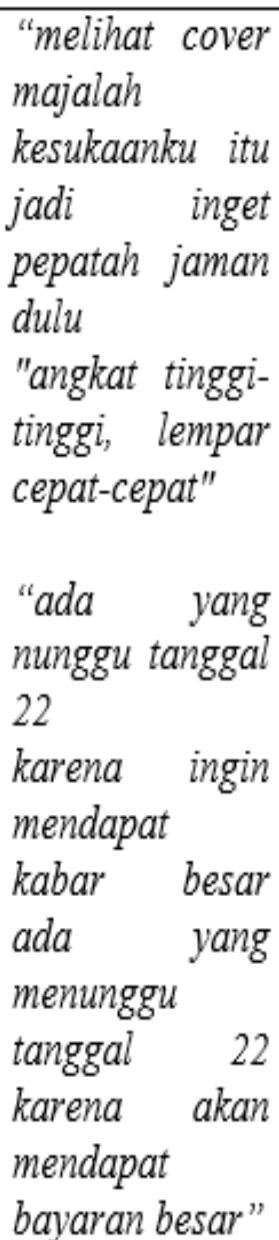 \\
\hline $\begin{array}{l}\text { Oktavia } \\
\text { Erwantoro }\end{array}$ & Penelit1 & $\begin{array}{l}\text { "dalam salat } \\
\text { fardhu subuh } \\
\text { nanti.jangan } \\
\text { lupa kita baca } \\
\text { doa Qunut } \\
\text { Nazilah untuk } \\
\text { Gaza.Amin." } \\
\text { "menulisku } \\
\text { mengeja malam } \\
\text { menjelang pagi. } \\
\text { Tapi sia sia } \\
\text { mengeja } \\
\text { itu.Baiklah..." }\end{array}$ \\
\hline
\end{tabular}

Based on the Facebook status above with different types of work can be analyzed as follows: Yudi Juniardi with his profession as a lecturer in English Language Education writes his status on
P-ISSN 2623-0062

E-ISSN 2622-9056

Facebook very neatly and directed both in content and writing. It also uses English mixing code such as do something (melakukan sesuatu) and head to head (satu lawan satu), only one error is found which is writing yg (yang). The second status is also written well and neatly following the correct writing rules such as the use of uppercase letters in the name of the country, namely Palestine and Allah.

The second object is the hulman Fajri with the profession as a teacher not much different from the first object, that is, has used good language and written it neatly and well-organized. There is only the use of nonstandard nyari (mencari) and abbreviations that are not appropriate kur (kurikulum).

The third object is a writer and cartoonist who certainly has the ability to write far better than other professions. In the first status there is no error and the second status is written as a poem with rhyma a-b a-b.

The third object, namely a researcher about language certainly has the ability and knowledge in writing. This is evidenced from the status that is made, neat, directed, and easily understood. There is only one mistake in writing repetitive words like sia-sia (sia-sia). 
Based on the analysis of the status of social media accounts, it can be concluded that the professional background is quite influential in the language used, including the register. As stated by Wardhaugh (2006) who describes registers as a set of 'language items' which are specifically related to occupational groups or social groups.

\section{c) Analysis of Social Variations in Language Users based on Social Institutions}

As an example of the social variation of language based on social institutions, the following is attached to the status on several Facebook social media accounts that have been categorized based on the age range of 24-30 years with high school, $\mathrm{S} 1, \mathrm{~S} 2$ and $\mathrm{S} 3$ education.

\begin{tabular}{|l|l|l|}
\hline Nama & $\begin{array}{l}\text { Pranata } \\
\text { sosial }\end{array}$ & $\begin{array}{l}\text { Status di } \\
\text { facebook }\end{array}$ \\
\hline $\begin{array}{l}\text { Susilo } \\
\text { Yudhoyono }\end{array}$ & Presiden & "Mari kita \\
bangun \\
akhlakul \\
karimah, \\
membantu \\
kaum dhuafa, \\
kaum miskin, \\
dan kaum \\
fakir. Mari ikut \\
tunjukkan \\
kepada dunia \\
bahwa Islam \\
adalah rahmat \\
bagi semesta \\
\end{tabular}

\begin{tabular}{|c|c|c|}
\hline & & $\begin{array}{l}\text { kediamannya } \\
\text { di Puri Cikeas, } \\
\text { Bogor, } \\
\text { kemarin (9/7) } \\
\text { Presiden SBY } \\
\text { memberikan } \\
\text { imbauan } \\
\text { kepada para } \\
\text { elite politik } \\
\text { agar bisa } \\
\text { menahan diri } \\
\text { sehingga tidak } \\
\text { memunculkan } \\
\text { ketegangan } \\
\text { yang } \\
\text { berlebihan di } \\
\text { antara kedua } \\
\text { massa } \\
\text { pendukung } \\
\text { capres \& } \\
\text { cawapres" }\end{array}$ \\
\hline $\begin{array}{l}\text { Ust. Yusuf } \\
\text { Mansyur }\end{array}$ & Ustad/Kiai & $\begin{array}{l}\text { "Belajar } \\
\text { mengaji } \\
\text { dibulan } \\
\text { Ramadhan, } \\
\text { lebih nambah } \\
\text { pahala dan } \\
\text { lebih khusyu } \\
\text { sampe waktu } \\
\text { berbuka, susul } \\
\text { sama doa." } \\
\text { "( PESAN } \\
\text { PENDEK } \\
\text { RAMADHAN } \\
\text { SEMAKIN } \\
\text { AKHIR } \\
\text { SEMAKIN } \\
\text { BESAR } \\
\text { PAHALANYA } \\
\text { Gak jamin } \\
\text { Ramadhan } \\
\text { depan bakal } \\
\text { kita nemuin } \\
\text { lagi. Waktu } \\
\text { manfaatin, } \\
\text { sedang }\end{array}$ \\
\hline
\end{tabular}


Volume 2 No. 1, Februari 2019

Universitas Banten Jaya
P-ISSN 2623-0062

E-ISSN 2622-9056

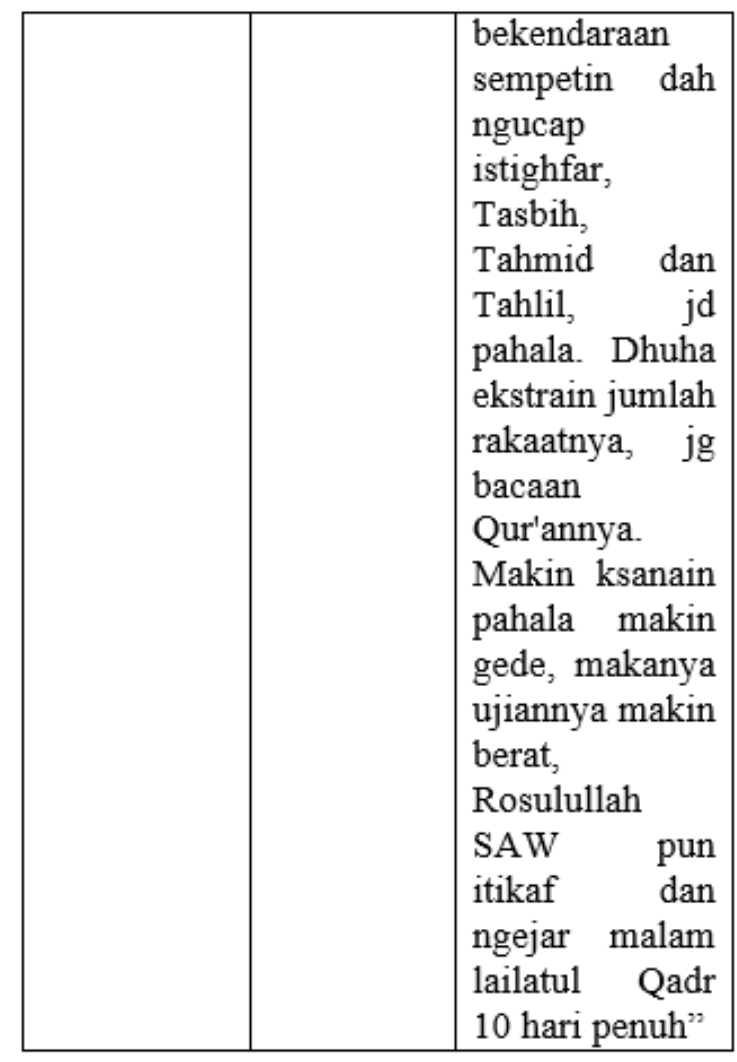

Based on the Facebook status above which came from two national figures, the first came from the official fanspage Mr. Susilo BambangYudhoyono had used EYD compliant writing both in word selection and in the way it was written. The second is from Ust's official fanspage. Yusuf Mansyur also did not find many mistakes, only a few must be corrected such as nambah (menambah), and sampe (sampai). In the second statement like as gak jamin (tidak menjamin), nemuin (menemukan), manfaatin (dimanfaatkan), sempetin (menyempatkan), ngucap (mengucap), jd (jadi), ekstrain (ditambah), jg (juga), Makin (makin), ksanain (nanti), makin (semakin), gede (besar), makin (semakin) and ngejar (mengejar). Edward Sapir and Benjamin Lee Whorf stated that social institutions are closely related to culture. The hypothesis states that speakers of languages classify the world according to the boundaries outlined by their native language. In this case because both of them are national figures and use the national language, namely Indonesian, there is no visible language classification that has been outlined, only its use certainly uses standard and formal Indonesian.

\section{SMP}

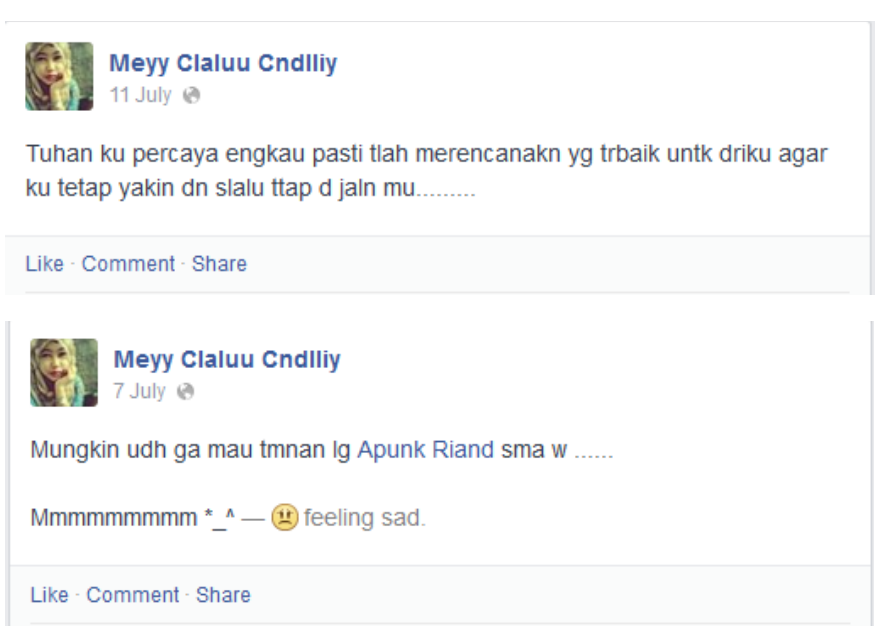

SMA

Selfy Zee

huujän menguyur mesuji dari jam 7 sore ampe menjelang jam $11 \mathrm{mlm} \mathrm{B \varepsilon} \underline{\varphi}_{\cdot}^{\mathrm{L}} \cdot \mathrm{M}$ reda..

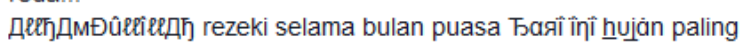
lamaaa, adeeeeee tarik selimut. 
(8)

Selfy Zee

4. July via BlackBerry Smartphones App (2)

(\{)

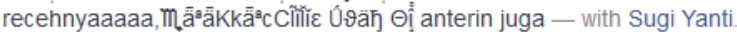

Like - Comment - Share

\section{S1}

\section{Taufiq Hidayat

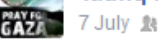

Membantu proses demokrasi.. dalam Pilpres 2014.. menjaga suara yang sudah di amanahkan rakyat.. agar tidak dicurangi.

Like - Comment - Share

\section{(3) Taufiq Hidayat}

Gat? 12 June $\theta$

${ }^{\left({ }^{n}\right)}$ Orang yang tidak mau mencoba untuk bergerak mengerjakan keinginanya, maka ia akan berusaha mengemukakan berbagai alasan da kendalanya sebelum mencoba.

\# "Selamat Mencoba"

Like - Comment - Share

\section{$\mathrm{S} 2$}

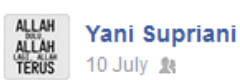

Kita lah yg telah dibantu oleh masyarakat gaza utk menyelamatkan temp isra'miraj nya Nabi kt (Al-Aqsa). Jadi masih bertanya "ngapain ngurusin gaza"?

Unlike - Comment - Share

AlaH Yani Supriani

AERus 5 July 28

Dua tahun lalu ngolahin data pasca upi jur. IPS temennya nani, sekrg ngolahin data jur. Psikologi ponakannya bu vidilla

Ternyata dunia sosial itu luaass dan lebih subjektif ternyata yah.

Like - Comment Share

\section{Dosen Pendidikan Bahasa Inggris}

$$
\begin{aligned}
& \text { Yudi Juniardi } \\
& 5 \text { hours ago \& }
\end{aligned}
$$

do something. dengan dalih apapun tidak dibenarkan suatu negara menyerang secara militer kedaulatan negara lain. jika ia anggota pbb, mak ia akan dikeluarkan keanggotaannya, seperti yg pernah dialami Indonesia tapi mengapa negara adidaya, dewan keamanan hanya diam? jika pada kondisi ini kangen presiden Soekarno atau mahatir muhammad yg berani head to head melaawan arogansi kaum kafir. Allahuakbar

Like - Comment - Share
Yudi Juniardi

11 hours ago $\&$

belajar dari kekalahan brazil: perlunya kaderisasi pemain handal jgn sekali-kali bergantung pada sosok pemain (single fighter)

Like · Comment $\cdot$ Share

\section{Peneliti}

Oktavia Erwantoro

Yesterday 24

dalam salat fardhu subuh nanti..jangan lupa kita baca doa Qunut Nazilah untuk Gaza.Amin.

Like - Comment Share

Oktavia Erwantoro

9 July 2

menulisku mengeja malam menjelang pagi. Tapi sia sia mengeja itu.Baiklah.

Like - Comment - Share

Guru

\&: Hulman Fajri

9 July 2

ketika manusia sudah dapat menempatkan dirinya sesuai dengan tugasnya, maka kebaikan yang akan tercapai... semoga .

\#perjalananrahasia

Like - Comment - Share

\section{Hulman Fajri}

19 June $\$$

peer teaching, siapa takut...!!

Lagi browsing nih hahahahaha

Nyari bahan besok peer teaching kur13

Like - Comment - Share

\section{Penulis}

Nassirun Purwokartun

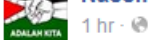

melihat cover majalah kesukaanku itu jadi inget pepatah jaman dulu

"angkat tinggi-tinggi, lempar cepat-cepat"

Like - Comment-Share

Nassirun Purwokartun

$1 \mathrm{hr} \cdot \mathrm{e}$

ada yang nunggu tanggal 22

karena ingin mendapat kabar besar

ada yang menunggu tanggal 22

karena akan mendapat bayaran besar

Like - Comment - Share 
Susilo Bambang Yudhoyono

11 July 2

Mari kita bangun akhlakul karimah, membantu kaum dhuafa, kaum miskin, dan kaum fakir. Mari ikut tunjukkan kepada dunia bahwa Islam adalah rahmat bagi semesta alam.

-Susilo Bambang Yudhoyono-

Susilo Bambang Yudhoyono shared a lin 10 July 2

Di kediamannya di Puri Cikeas, Bogor, kemarin (9/7) Presiden SBY memberikan imbauan kepada para elite politik agar bisa menahan diri sehingga tidak memunculkan ketegangan yang berlebihan di antara kedua massa pendukung capres \& cawapres.

\section{Ust. Yusuf Mansyur}

Belajar mengaji dibulan Ramadhan, lebih nambah pahala dan lebih khusyu sampe waktu berbuka, susul sama doa.

Yusuf Mansur Network Yesterday $\theta$

( PESAN PENDEK) RAMADHAN SEMAKIN AKHIR SEMAKIN BESAR PAHALANYA

Gak jamin Ramadhan depan bakal kita nemuin lagi. Waktu manfaatin, sedang bekendaraan sempetin dah ngucap istighfar. Tasbih. Tahmid dan Tahlil, jd pahala. Dhuha ekstrain jumlah rakaatnya, jg bacaan Qur'annya. Makin ksanain pahala makin gede, makanya ujiannya makin berat, Rosulullah SAW pun itikaf dan ngejar malam lailatul Qadr 10 hari penuh.

Unlike Comment Share

\section{Conclusion}

Language variations occur not only because of the different interaction activities of each human being but also because of the non-homogeneous speakers. Each speaker performs a different activity and certainly has different interactions every time. Language variations based on speakers can be distinguished based on the number of speakers, age, gender, social status, and culture (environment). Social status itself can be distinguished based on work and education.
Language variations based on work such as differences in vocabulary on communication of workers, traders, teachers, doctors, artists, and others. Each job has its own vocabulary, which can only be understood by them.

Based on the level of education, variations in language can be seen not only in the content of the conversation but the extent of the vocabulary they have. In general, the higher the education pursued, the wider the vocabulary owned. In addition to the pronunciation of the words used. In general, someone who takes a higher education will master language pronunciation far better than people who do not take education. For example, there is a clear difference between a person's communication vocabulary and the background of a junior high school education with students.

In this study social institutions do not appear to affect the variation of language used, because the two respondents studied were national figures. The language used is Indonesian which is standard, formal, and in accordance with EYD

\section{References}

Cahyono, Bambang Yudi. 1995. KristalKristal Ilmu Bahasa. Surabaya: Airlangga University Press. 
Volume 2 No. 1, Februari 2019

P-ISSN 2623-0062

Universitas Banten Jaya

E-ISSN 2622-9056

Chaer, Abdul. 2010. Sosiolinguistik:

Perkenalan Awal. Jakarta: Rineka Cipta.

Halliday, M.A.K. dan Ruqaiya Hasan. 1996. Bahasa, Konteks, dan Teks.

Yogyakarta: Gadjah Mada

University Press.

Hasan, Ruqaiya. 2005. Language, Society, and Consciousness. UK: Equinox

Publishing Ltd.

Wardhaugh, Ronald. 2006. An Introduction to Sociolinguistics. Oxford: Blackwell

Publishing.

Wira, I Made. Sistem Kasta di Bali. Juli

2014. <http://imadewira.com/sistem-kasta-

di-bali/> 